\title{
Resources and Constraints of Line Manager Agency in Municipal Reforms
}

I Tuula Heiskanen'

Research Director, Docent, Work Research Centre, University of Tampere, Finland

I Esa Jokinen

Researcher, M.Soc.Sci, Work Research Centre, University of Tampere, Finland

\begin{abstract}
The context of this study is the nation-wide reform of local government in Finland, focusing on line managers and their scope of agency. Our data comprise two large-scale surveys of 40 municipalities in 2009 and 38 in 2011. The respondents were line managers from different levels of the hierarchy and, for comparative purposes, staff from the same units. Resources and constraints of agency were studied both in relation to the immediate work of the respondents and to the broader issues of municipality reform. Broad-scale reforms proceed in stages that require different forms of agency. Predominantly, a higher position in the hierarchy seemed to give better conditions for agency, but this was not always the case. Notable were the high values for intrinsic rewards of work given by all groups, indicating the existence of conditions that enable new cognitive and learning challenges to be met. It seems that this potential was not actualized satisfactorily in the accomplishment of development activities. The supervisor's influence on the social climate of the units was evident in the longitudinal setting. From the perspective of distributed agency, this result is highly significant when one considers that the social environment is the immediate context of agency.
\end{abstract}

\section{KEY WORDS}

Line Managers / Agency / Municipal Reform / Levels of Hierarchy

\section{Introduction}

he context of this study is the nation-wide reform of local government in Finland. Reforms in local government are on the political agenda in many countries. While the specific structures and tasks of the local governments differ from country to country, the need to find ways to provide services to citizens in cost-effective ways is a common driving force behind the reforms (Denters \& Rose 2005; Dollery et al. 2008; Macleod \& By 2009). Reforms typically start from political interests, and rapid results are typically expected (e.g., Haveri 2008). However, the incremental nature of organizational changes and the microprocesses that lead to them do not fit well with these expectations (e.g., Meklin \& Pekola-Sjöblom 2013). This article focuses on the daily life of the organizations undergoing reform, and more specifically on line managers and their scope of agency in relation to the organizational changes.

\footnotetext{
${ }^{1}$ E-mail: tuula.heiskanen@uta.fi
} 
Earlier research shows a variety of views on the similarities and differences between the public and private sectors in regard to change management. Some features that traditionally distinguished the public and private sectors have become blurred (e.g., the development of public-private partnerships and the ownership of public goods), while some other features in the conditions of the strategic and operating environments continue to differentiate the sectors from each other (e.g., Macleod \& By 2009). There is some controversy as to how the differences between the sectors influence the work of managers (Poole et al. 2006). The image of middle managers as neutral administrators in the public sector implies they have a minor scope of influence on strategic matters related to organizational changes. On the other hand, there are also views that see public middle and line managers not only as targets but also as potential agents of change (Caldwell 2009). However, these diverging views do not have a firm empirical basis in either direction. In spite of the increased interest in the roles of middle and line managers in organizational change processes (e.g., Wooldridge et al. 2008), this growth of research is not visible in studies related to the work of the public sector in general or municipalities in particular. In any case, one can assume that in comparison to private organizations, the scope and kind of agency of the organization members are different in municipalities-for example, due to the fact that municipal reforms have a much wider variety of players and stakeholders who might have an influence on the objectives and processes of the reform.

In management studies dealing with the issue of managerial agency, the strategy process receives the most interest. Here, however, the quality of line managers' own work and their position in the organization are the starting points from which agency is examined. Along with some organization studies (e.g., Balogun 2003; Dutton et al. 2001; Huy 2002), the study assumes line managers to have some sort of intermediary role in the processes of change where their actions and behaviors might have some influence both upward and downward in the organization. The empirical data provide material to examine whether such an intermediary role is truly the case. Relying on data from 40 municipalities responding in one way or another to restructuring demands, this study examines the resources and constraints of line manager agency and focuses both on the managers' opportunities to influence the reform process in the broad sense and on their immediate work with their subordinates.

\section{The context: reforms in municipalities}

Local governments in most contemporary democracies face transformations in their operating environment (Denters \& Rose 2005). The difficult combination of increased service demands and reductions in public spending is familiar in many countries (Moisio 2012; Rose \& Ståhlberg 2005, p. 99). The new demands have led to broad-scale reforms in administrative and operational structures in order to meet the future needs of service production and delivery (Wollman 2012). Amalgamations of municipalities are often means used in the reforms, but less strict forms of cooperation between the municipalities are also in use in different countries (e.g., Dafflon 2012; Slack \& Bird 2012).

The reform in Finland, to which this article relates, is known as the PARAS project (the project to restructure local government and services). It was governed by a framework act (Act on Restructuring Local Government and Services 169/2007) that set the 
objectives and means for the desired reform. In Finland, like in the other Nordic countries, the municipalities' responsibilities for service provision-including health care, social welfare, and education-are exceptionally broad (e.g., Borge \& Rattso 2012; Moisio 2012; Naschold 1996; Pollitt \& Bouckaert 2000, pp. 42-43). By law, all Finnish citizens are entitled to receive the same basic services irrespective of their place of residence. One particular challenge of service provision, especially in health care, is the relatively small size of the municipalities. The framework act for the PARAS project defined three sets of means by which a comprehensive and economically sustainable service structure should be achieved. The means were municipal mergers, the establishment of partnership areas, and the strengthening of operation prerequisites in urban areas (Blöchliger \& Vammalle 2012, pp. 83-92).

The reform has been evaluated by the multidisciplinary and multiactor ARTTU (evaluation research) program, on which this study is based (Meklin \& Pekola-Sjöblom 2010). The evaluation program selected forty municipalities that represented different structural solutions (mergers, cooperation areas, no major structural changes). Irrespective of the chosen reform model, many kinds of reform activities have taken place throughout the municipality sector. Changes related to management systems in general, including organizational structures, the division of power and responsibilities between elected officials and local government officers, the roles of different actors, and management processes. For example, the application of a life-course model or process management, as well as a purchaser-provider model, has brought a number of changes to the internal operation of the municipalities.

The development of local government after PARAS has continued under the label 'Municipality reform.' According to the Government Programme (CS 2011), the new reform comprises: 1 ) the new Act on the municipal structure (478/2013), which obliges most municipalities to participate in working out municipality structures; 2) reform on social and health care service structure; 3 ) reform on the state subsidy system; 4) reform on the Local Government Act; and 5) the mapping of municipal tasks (AFLRA 2015).

\section{Theoretical Background}

The study focuses on line managers in different levels of the hierarchy in reforming municipalities. In management literature and practice, the term 'line manager' refers to a manager who contributes directly to the output of products and services. On the other hand, it has been noted in research that line management may intersect other functions in organizations. For example, the human resource management (HRM) literature has shown that line managers may have a critical role in HRM practices in addition to their customary tasks (e.g., Brewster et al. 2013). The term 'middle managers' in part overlaps 'line manager' in use, but the usage of the term typically excludes the lowest level of managers that are often called supervisors (Wooldridge et al. 2008, p. 1192). For simplicity, 'manager' refers to all of these levels in this article.

The term 'line manager' underlines the differences between certain functions, for example, between core, human resource and finance functions, and it has been studied in HRM research. The term 'middle manager' draws attention to the intermediary role of the manager between the top managers and subordinates, and this term has been used, for example, in studies of strategy-making processes (e.g., Wooldridge et al. 2008). The 
study of organizational change has highlighted the need to better understand the alternatives to top-down change processes; in addition, it has increased interest in what the dispersal of change responsibilities to different levels of the organization means from the perspective of the line or middle manager (Bryant \& Stensaker 2011; Caldwell 2005). In this study, the inclusion of different management levels follows specifically from the assumption of the devolution of autonomy to agents on different levels, and the significance of this devolution in change contexts.

There are some relatively established strands of research concerning line or middle managers. A number of studies have focused on the roles of managers. The primary role of line managers is typically seen to be the supervision of their subordinates in the implementation of plans concerning production or services made by the upper levels of the organization. The literatures on change management and strategic processes have, however, presented a more differentiated picture about what the role is or might be. Balogun (2003, p. 70), for example, thinks that 'middle managers are best characterized as change intermediaries fulfilling four interrelated roles during change implementation-undertaking personal change, helping others through change, implementing necessary changes in their department and keeping the business going.' In the intermediary role between different levels of the organization (Nonaka 1994, pp. 29-30), middle managers influence the strategic agenda by selling issues upward (Dutton et al. 2001; Wooldridge et al. 2008) and by promoting strategic change downward (Huy 2002). Bryant and Stensaker (2011) summarize the role expectations on line and middle managers: managers may simultaneously handle issues related to implementing change (substantive concerns), keep senior managers happy (political concerns), and address the interests and anxieties of employees (relational concerns).

There is one especially extensive and long-lived strand of studies dealing with line managers. It deals with the reciprocal exchange between a leader and follower, acknowledging that both parties contribute to the development and maintenance of the relationship (Gerstner \& Day 1997). Studies have focused on the individual-, group-, and organization-level outcomes of the dyadic relationship. Examples of frequently measured outcomes are follower satisfaction, commitment, and performance. The critique of the research line has brought forth an asymmetry in the available research, which shows that leaders' perspectives or shared perceptions are clearly underrepresented (Paglis \& Green 2002; Schyns \& Day 2010).

Another strand of studies relates to HRM. While the aforementioned studies belong to an established tradition with regard to focus and methodology, the studies linking HRM and line managers show greater variation. It has been observed in different countries that HR tasks such as pay and benefits, recruitment and selection, training and development, and industrial relations and workforce expansion or reduction have been increasingly devolved to line managers; these tasks are performed either alone or together with the HR department (Larsen \& Brewster 2003). However, this transfer of tasks is problematic and may cause tension between operational and people-related tasks, and it may lead to feelings of overload (McConville 2006). In addition to the sharing of roles between HR function and line managers, the effects of the line managers' contributions to HR practices on employee perceptions, reactions, and performance have received the attention of researchers (e.g., Alfes et al. 2013; Bos-Nehles et al. 2013; Brewster et al. 2013).

To conclude, earlier studies have convincingly shown that line manager behavior is related to employee experiences, perceptions, and performance. Less studied, however, is 
the question of what kinds of resources line managers are using to enact their multiple responsibilities. This question is especially warranted in organizational change situations.

Line managers are both affected themselves by change and have an effect on how change is implemented. Thus, they can be recipients of change and change agents at the same time (Bryant \& Stensaker 2011; Caldwell 2003; Newell \& Dopson 1996). As a consequence of the multiple responsibilities of the line managers, the agency of change can take place in different fields. Caldwell (2009) has differentiated two main types of agency: strategic agency and sense-making agency. Strategic agency refers to the proactive involvement of middle managers in strategic change in addition to their intermediary implementation role. Sense-making agency refers to attempts to interpret and make sense of the events and outcomes of the intended change. These two concepts embrace different aspects of agency in situations of change, but Caldwell thinks that neither of them are sufficient for understanding managerial agency. According to Caldwell, the limitation of strategic agency is that it treats management functions in a deliberate strategy process without a view to the emergent aspects of organizational change. In sensemaking agency, the primary focus is on the emergent or interactional nature of strategy. One of the limitations, according to Caldwell, of studies made within the sense-making framework is the lack of focus on proactive managerial functions rather than on simply reactive forms of behavior. Caldwell calls for approaches and studies that acknowledge the distributed or decentered nature of agency and reveal the enabling and limiting conditions of managerial roles.

Anthony Giddens' writings have had a wide impact on understandings of agency in social sciences, and his thinking is used here to open a perspective on conditions for human action to be considered agentic. In his definition, agency concerns events which an individual perpetrates, first in the sense that he/she could have acted differently, and second in that whatever happened would not have happened if that individual had not intervened (Giddens 1984, pp. 14-15). Giddens argues that the necessary conditions for agency are, first, that the actor is capable of doing things that follow from his/her intentions and that he/she has the option and power to make a different choice. In this study, our interest is in the organizational context rather than on individual-level analysis. We acknowledge the individual variation of professional agency even in similar kinds of conditions, as studied in subject-centered approaches to agency (Eteläpelto et al. 2013). Here, however, we limit our analysis to the resources provided and constraints set for agency by the organizational context and working conditions, rather than on the practice of agency.

Our research focuses on the resources and constraints for agency arising from three different sources: from the implementation approach of the reform, from the job itself, and from the social environment of work. In the implementation approach, we are interested in how this approach distributes opportunities to participate in the planning of the implementation process. Our assumption is that in the implementation approaches, there is an issue of the degree of participation rather than the existence/nonexistence of participation (cf. Russ 2008, p. 200). At the same time, we are aware that participation is a complex issue containing a number of different forms (Lines 2004). Here we only deal with direct participation (e.g., Poutsma \& Veersma 2010).

Starting from the classic studies of working life democracy (e.g., Emery \& Thorsrud 1969 ) and the quality of working life movement (Davis \& Cherns 1975), autonomy has been the key issue in working life studies, and it has also been considered the most effective form of direct participation as regards the quality of work (Gallie 2013). It is also 
of the utmost importance as regards agency at work (Caldwell 2009, p. 92). Besides job autonomy, some other aspects of job quality should be considered as potential resources or constraints for agency. Taking into account the fact that line managers should support their subordinates' development opportunities in the context of change and mediate innovative ideas and solutions upward, the kinds of learning and self-development opportunities their own work provides are significant. For example, Eteläpelto et al. (2013) consider it essential to include both individual development opportunities and sociocultural and material resources and constraints when studying professional agency.

Organizational change has much to do with communicative action (Allen et al. 2007; Jansson 2013). Organizational change almost always brings with it tensions and conflicts that have an effect on the social climate of the workplace and through it on employee actions (Tierney 1999). Line managers have an essential role in providing information about the implementation downward (Allen et al. 2007) and how the change in general is talked about in the work community (Karp \& Helgo 2008). We deal with the social environment of the workplace in a dual way. First, we think of a social environment as a resource or constraint for the line managers in performing their work activities (e.g., Giauque 2015). Second, we think that their agency is visible in the social environment and quality of the social interaction in the work communities.

The roots of theories that deal with agency differ (Caldwell 2005; Eteläpelto et al. 2013) and each of the approaches has some limitations. The need to understand agency in organizational change is one of the core questions of change management and it requires both theoretical work and empirical knowledge. The focus on line managers in public sector reforms is not a typical field in the research of agency. There are some preliminary assumptions which explain, at least partly, the scant attention to such issues in the public sector. In particular, the image of public line managers solely as administrators might be behind the limited attention given to them from the perspective of agency. Here we do not assume, a priori, any special model of opportunities to participate in the organizational change process, but let the empirical material speak for itself. The inclusion of managers from different hierarchical positions allows the study to make visible the ways resources and constraints are distributed in the organizations.

In the study, we ask the following questions:

1. How do managers on different levels of the hierarchy experience their opportunities to exercise influence at work and to develop themselves?

2. How do managers on different levels of the hierarchy perceive their opportunities to influence the changes taking place in the municipalities?

3. How do the staff's experiences of the supervisors' ways of functioning relate to the social climate of the workplace?

4. How does the change in the way the supervisors function relate to the social climate, the intrinsic rewards of work, and opportunities to exercise influence through the municipalities' aggregate-level data?

\section{Data and methods}

The study employs comprehensive survey data on the quality of the working life of employees undergoing the PARAS reform. The data were collected from 40 municipalities 
in 2009 and 38 municipalities in 2011 ( $n=3,710$ and $n=4,618$ respectively, reply rates $60 \%$ and $52 \%$ ). The municipalities selected represent different sizes and types of municipality. The target municipalities represent the Finnish field of local government in regard to different structural reform categories, population size, rural/city categories, linguistic divisions, industrial structure, age structure, and geographical location (Jokinen \& Heiskanen 2013). One third of the municipalities in this study have been formed through municipal mergers, another third consist of cooperation areas and the remaining third are regular municipalities that have not undergone any major structural reforms.

The survey was directed at employees in the social and health sector and the education sector, and in 2011, also at employees in the administration sector. On the whole, the respondents correspond well to the total population in the local government. The proportion of female respondents was $89 \%$ in 2009 and $85 \%$ in 2011, while their total share in local government as a whole was $81 \%$ in 2010 . In addition, the age distribution follows approximately the same pattern in the surveys as in the population. Studies on middle and/or line managers typically treat them as a single group, which can be considered a limitation. This study is based on the assumption that the hierarchical and functional positions of the managers produce variation in the kind, degree, and conditions of agency. The research setting involves line managers from different levels of the hierarchy, and, to enable comparisons, staff from the same units. In this article, the respondents are classified into four categories (Table 1): 1) staff, 2) first-level managers whose subordinates do not have subordinates, 3 ) second-level managers whose subordinates have subordinates, and 4) third-level managers whose subordinates and their subordinates have subordinates.

Some sources of nonresponse bias were detected during the research process and corrective actions were taken where possible. In 2009, all 40 municipalities taking part in the ARTTU program also participated in the survey study. In 2011, two municipalities did not participate as they were participating in some other studies at the same time. The survey was conducted using paper questionnaires sent by regular mail in 2009 and using a web-based tool in 2011. Hence, the web-based survey caused some bias, excluding in particular some social and health sector workers. Due to this, a second smaller survey $(n=1,373)$ using paper questionnaires was conducted. To achieve the best possible reply percentages, at least one reminder message was sent to nonrespondents in both years, several in the case of the web-based survey.

The analysis proceeds mainly with sum scales related to the general quality of working life and with individual items. The sum scales are: 1) intrinsic rewards of work, 2) work influence, 3) social climate at workplace, 4) open ways to solve work conflicts, and 5) supervisory work (for items and alpha coefficients in sum scales, see Appendix).

Table I Respondents according to the occupational position in 2009 and 201 I (frequencies)

\begin{tabular}{cccccc}
\hline Staff & $\begin{array}{c}\text { Manager first } \\
\text { degree }\end{array}$ & $\begin{array}{c}\text { Manager second } \\
\text { degree }\end{array}$ & $\begin{array}{c}\text { Manager third } \\
\text { degree }\end{array}$ & Total \\
\hline 2009 & 3,121 & 275 & 42 & 14 & 3,452 \\
\hline 2011 & 3,989 & 457 & 70 & 26 & 4,542 \\
\hline
\end{tabular}


Intrinsic rewards of work and influence at work are also presented item by item. The participation of employees in the PARAS reform originally included fifteen items, of which this study uses 'participation in the reform planning' and 'information received related to the reform.' Further, individual items are used in 'opportunities to participate in the development of the workplace' and in 'information about changes related to one's own work.' Statistical methods and relevant statistical tests are used in presenting the results (Table 2).

\section{Results}

To begin the analysis, the potential differences between reform municipalities ('major reform') and those municipalities where no such major reform had taken place ('no major reform') were examined. The variables used were 'overall quality of working life' and separately its subdimensions 'opportunities to influence social interaction,' 'ways of handling conflicts, 'intrinsic rewards of work,' and 'supervisory work.' Comparisons between the types of municipalities were firstly made for each year; in the total samples the differences proved to be minor. Secondly, comparisons between 'major reform'/'no major reform' municipalities were made separately for the staff (as one group) and managers (as another group). Similar trends in both types of municipalities were found. 'Intrinsic rewards of work' and 'supervisory work' had improved in both types of municipalities and were considered better both for the staff and for the managers. However, the differences (2009 vs 2011) were statistically significant $(\mathrm{p}<0.05)$ in 'intrinsic rewards' only in the staff answers and in 'supervisory work' in the staff answers in the 'major reform' and in the manager answers in the 'no major reform municipalities.' 'Conflict handling' had been impaired to some extent in the 'no major reform municipalities' $(\mathrm{p}<0.05)$. Since the results do not differ in any systematic way between the 'major reform' and the 'no major reform' municipalities, the following analyses proceed without differentiation according to the type of municipality.

The variable 'influence at work' showed a pattern according to the hierarchical level of the respondent groups (Figure 1). The biggest difference, however, is between the staff and manager groups. Closer examination of the variable item by item reveals the areas

Table II Empirical design

\begin{tabular}{lll}
\hline Contexts of agency & Resources and constraints & Analysis \\
\hline Immediate work & $\begin{array}{l}\text { Influence at work } \\
\text { Intrinsic rewards of work } \\
\text { Information received }\end{array}$ & $\begin{array}{l}2009 \text { and 20 I I descriptive } \\
\text { statistics all groups }\end{array}$ \\
\hline $\begin{array}{l}\text { Immediate social } \\
\text { environment }\end{array}$ & Supervisor's way of functioning & $\begin{array}{l}2009 \text { and 20 I I correlations within } \\
\text { staff and manager groups }\end{array}$ \\
& Social climate & $\begin{array}{l}\text { Aggregate-level correlations } \\
\text { indicating change 2009-20 I I }\end{array}$ \\
\hline $\begin{array}{l}\text { Reform on } \\
\text { municipality level }\end{array}$ & Possibilities to participate & $\begin{array}{l}2009 \text { and 20 I I descriptive } \\
\text { statistics all groups }\end{array}$ \\
\hline
\end{tabular}


Figure I: Influence at work according to the occupational position in 2009 and 201 I (means).

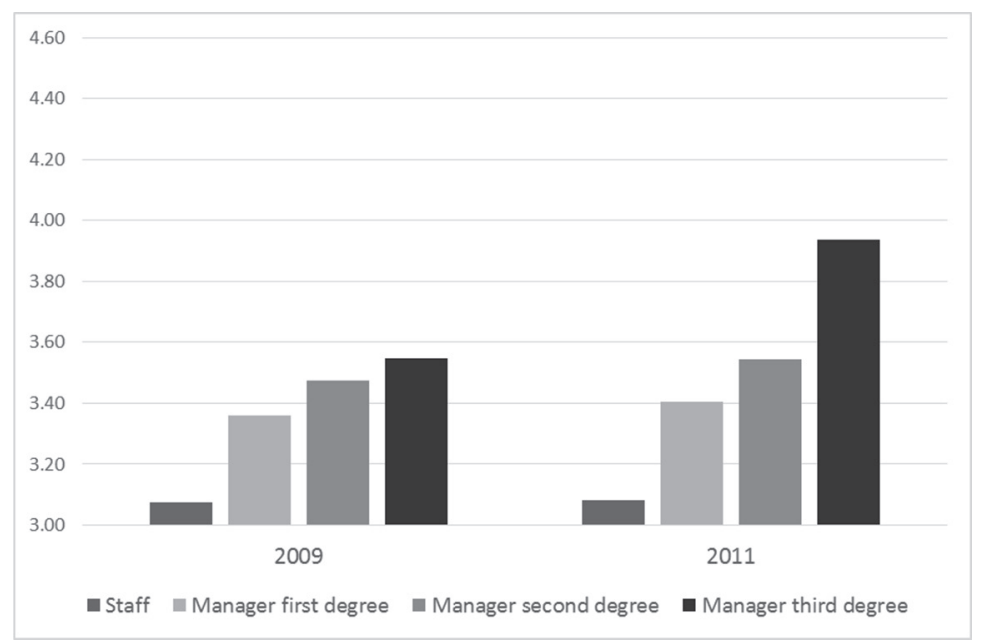

Table III Good opportunities for influence at work according to the occupational position (percentages in 2009 and 2011 )

\begin{tabular}{|c|c|c|c|c|c|c|c|c|c|c|}
\hline \multirow{3}{*}{$\begin{array}{l}\text { Work influence } \\
2009 / 20 \text { II on }\end{array}$} & \multicolumn{10}{|c|}{ Position } \\
\hline & \multicolumn{2}{|c|}{ Staff } & \multicolumn{2}{|c|}{$\begin{array}{c}\text { Manager } \\
\text { first degree }\end{array}$} & \multicolumn{2}{|c|}{$\begin{array}{c}\text { Manager } \\
\text { second degree }\end{array}$} & \multicolumn{2}{|c|}{$\begin{array}{c}\text { Manager } \\
\text { third degree }\end{array}$} & \multicolumn{2}{|c|}{ Total } \\
\hline & 2009 & 2011 & 2009 & 2011 & 2009 & 2011 & 2009 & 2011 & 2009 & 2011 \\
\hline - working methods & 62 & 63 & 70 & 70 & 64 & 74 & 72 & 77 & 63 & 64 \\
\hline - order of tasks & 57 & 60 & 74 & 79 & 81 & 79 & 79 & 89 & 58 & 63 \\
\hline - pace of work & 35 & 34 & 39 & 41 & 48 & 39 & 21 & 46 & 35 & 35 \\
\hline - workplace goals & 30 & 30 & 72 & 70 & 74 & 79 & 93 & 92 & 34 & 35 \\
\hline $\begin{array}{l}\text { - how work is } \\
\text { being divided }\end{array}$ & 30 & 29 & 56 & 59 & 57 & 65 & 64 & 81 & 33 & 33 \\
\hline $\begin{array}{l}\text { - what is included } \\
\text { into tasks }\end{array}$ & 30 & 31 & 35 & 41 & 21 & 53 & 50 & 73 & 30 & 33 \\
\hline $\begin{array}{l}\text { - educational } \\
\text { contents } \\
\end{array}$ & 14 & 19 & 46 & 50 & 67 & 79 & 72 & 81 & 18 & 23 \\
\hline $\begin{array}{c}\text { - whom you are } \\
\text { working with }\end{array}$ & 11 & 12 & 17 & 22 & 27 & 34 & 29 & 42 & 12 & 13 \\
\hline $\begin{array}{c}\text { - acquisition of } \\
\text { equipment }\end{array}$ & 7 & 10 & 33 & 33 & 45 & 40 & 72 & 62 & 10 & 13 \\
\hline
\end{tabular}

Answers 'much' or 'very much.'

where opportunities for influence existed or did not exist (Table 3). Since the number of the respondents among the third-level managers is small, one should not pay too much attention in their case to the exact percentages but rather to the general trends. 'Influence on work methods' and 'order of work' scored relatively highly among all groups. With the 
exception of 'pace of work,' the dividing line between the staff and managers was marked in the other items. There was an especially large difference in 'setting of the objectives of the workplace' and 'defining contents of education.' Differences between the first- and second-level managers were altogether small. An exception to this is 'contents of education,' where second-level managers had more influence than the first-level managers in both years.

In 'intrinsic rewards of work,' the overall level is quite high (Figure 2). There is a slight increase in the level from 2009 to 2011. The difference between the staff and manager groups is clear, even though the staff group also has high values. The highest scores by all the groups are in the items 'work requires responsibility,' 'one can use one's know-how at work,' and 'work is interesting' (Table 4). In the first two variables, the majority of all respondent groups answered using option 5: 'the description applies to a great extent.'

As the previous variables show relatively similar patterns in 2009 and 2011, the variable 'opportunities to participate in the development of workplace' diverges from the picture. There is a clear decline among all the manager groups in the percentages of those who said they had good 'opportunities to participate in the development' (Figure 3). A similar decline is also visible in the variable 'information about changes concerning your work.' In the manager groups, the answer alternative 'already in the planning stage' has clearly declinew.

While the previous variables referred to the immediate work and workplace of the respondents, the variables 'opportunities to participate in the planning of the reform' and 'information about the reform' have a broader scope and may refer to the whole municipality. 'Opportunities to participate in the reform planning' had increased to

Figure 2: Intrinsic rewards at work according to the occupational position in 2009 and 2011 (means).

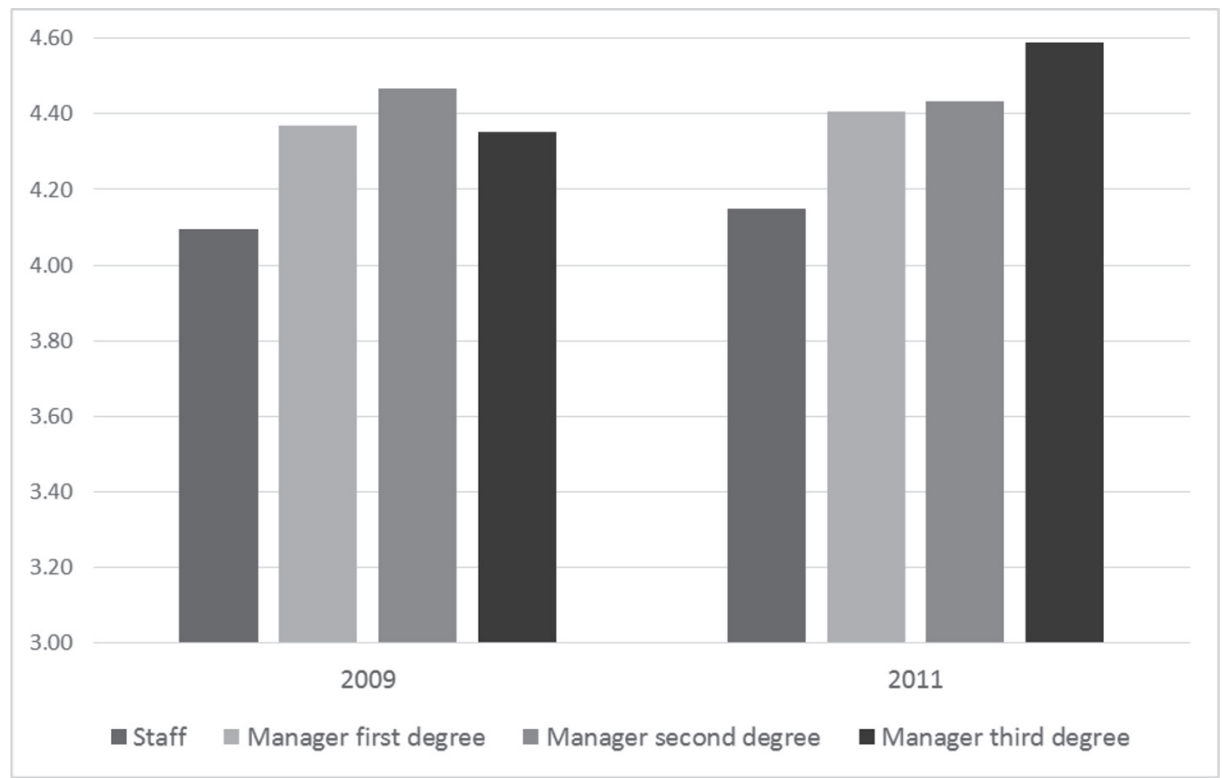


Table IV Intrinsic rewards at high level according to the occupational position (percentages in 2009 and $20 \mathrm{II}$ )

\begin{tabular}{|c|c|c|c|c|c|c|c|c|c|c|}
\hline \multirow{3}{*}{ Intrinsic rewards } & \multicolumn{10}{|c|}{ Position } \\
\hline & \multicolumn{2}{|c|}{ Staff } & \multicolumn{2}{|c|}{$\begin{array}{c}\text { Manager } \\
\text { first degree }\end{array}$} & \multicolumn{2}{|c|}{$\begin{array}{c}\text { Manager } \\
\text { second degree }\end{array}$} & \multicolumn{2}{|c|}{$\begin{array}{c}\text { Manager } \\
\text { third degree }\end{array}$} & \multicolumn{2}{|c|}{ Total } \\
\hline & 2009 & 2011 & 2009 & 2011 & 2009 & 2011 & 2009 & 2011 & 2009 & 2011 \\
\hline $\begin{array}{c}\text { - work requires } \\
\text { responsibility }\end{array}$ & 97 & 96 & 100 & 99 & 98 & 97 & 100 & 96 & 97 & 96 \\
\hline $\begin{array}{l}\text { - work allows } \\
\text { self-development }\end{array}$ & 65 & 70 & 86 & 88 & 90 & 89 & 71 & 92 & 67 & 72 \\
\hline - work is interesting & 84 & 86 & 94 & 95 & 93 & 90 & 100 & 96 & 85 & 87 \\
\hline $\begin{array}{l}\text { - work requires me } \\
\text { to learn new things }\end{array}$ & 78 & 83 & 90 & 95 & 95 & 96 & 100 & 88 & 79 & 84 \\
\hline - work is varied & 78 & 81 & 90 & 91 & 93 & 93 & 86 & 96 & 80 & 82 \\
\hline $\begin{array}{l}\text { - one can use one's } \\
\text { know-how in work }\end{array}$ & 92 & 92 & 96 & 95 & 95 & 94 & 86 & 100 & 92 & 93 \\
\hline $\begin{array}{l}\text { - one can achieve } \\
\text { one's goals in work }\end{array}$ & 69 & 71 & 86 & 84 & 88 & 87 & 71 & 96 & 70 & 73 \\
\hline
\end{tabular}

Answers: 'Description applies pretty or very well'

Figure 3: Good opportunities to participate in the development of the workplace according to the occupational position, percentages in 2009 and 2011 .

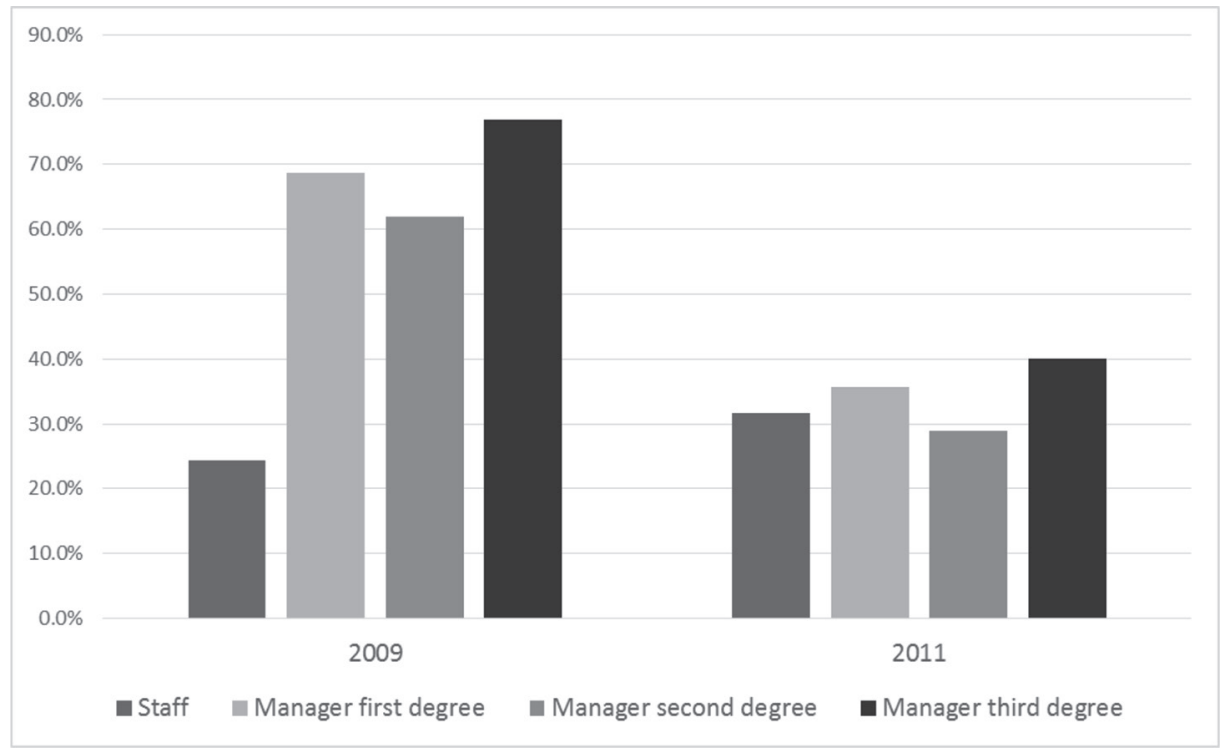


Figure 4: Information about changes concerning one's own work (percentage distributions according to the occupational position in 2009 and 201 I).

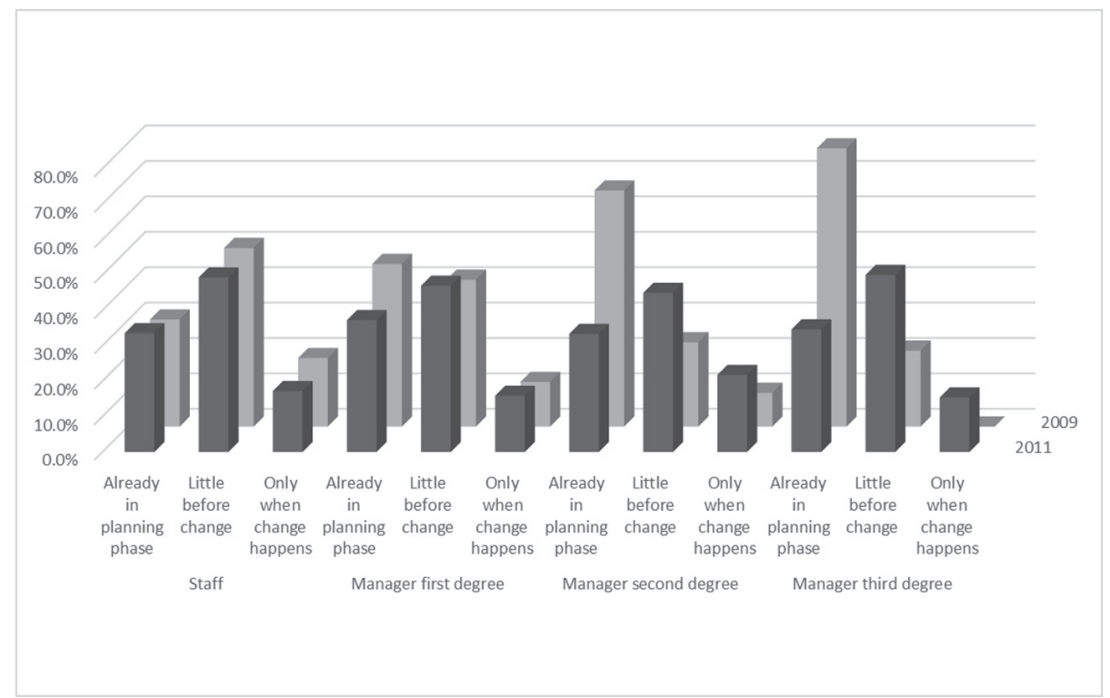

Figure 5: Participation opportunities in reform planning according to the occupational position in 2009 and $201 \mathrm{I}$ (means).

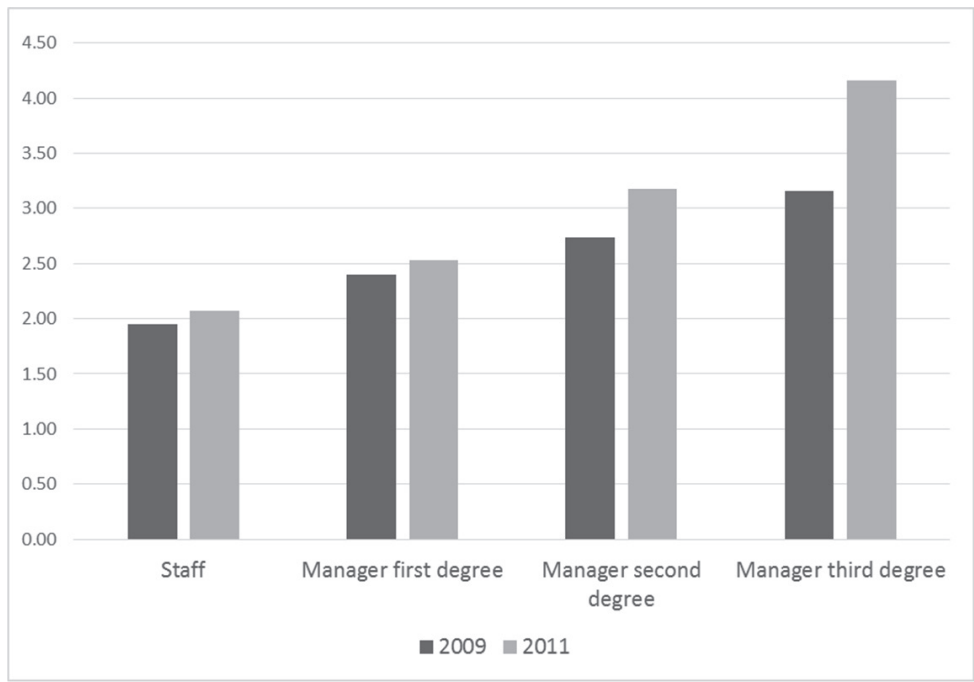

some extent from 2009 to 2011 and differed very clearly according to the groups, following their hierarchical order (Figure 5). The same applies to the information about the reform (Figure 6). All in all, quite a small percentage of the staff $(9 \%$ in $2009 / 9 \%$ in 2011 ) and first-level managers $(19 \% / 25 \%)$ considered themselves as having 'opportunities to participate in the planning stage' and to have received enough information (staff: 
Figure 6: Sufficient information about the reform according to the occupational position in 2009 and $201 \mathrm{I}$ (means).

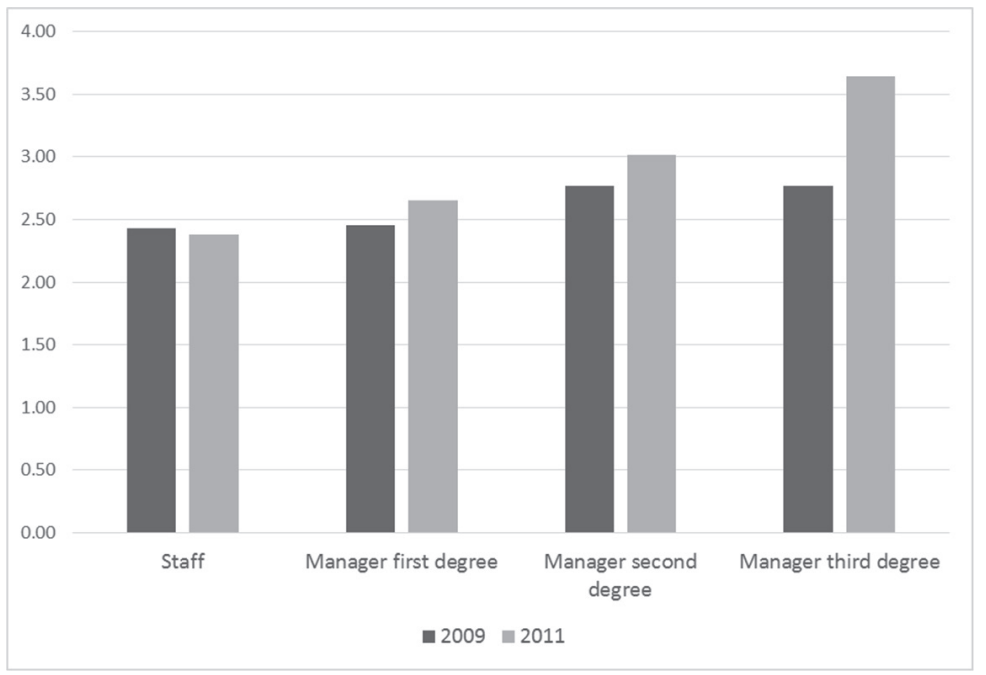

Table V Correlations between the manager's way of functioning and social climate in 2009 and 2011

\begin{tabular}{ccc}
\hline Year & Staff group & Manager group \\
\hline 2009 & $0.65^{\times \times x}$ & $0.50^{\times x}$ \\
\hline 2011 & $0.68^{\times \times x}$ & $0.46^{\times \times x}$ \\
\hline
\end{tabular}

Note: Statistical significance: ${ }^{x \times x} p<0.001,{ }^{x \times} p<0.01$.

21\%/16\%; first-level manager: $18 \% / 24 \%$ ). Among the second-level and especially the third-level managers, the percentages were clearly higher both in participation (secondlevel: $29 \% / 44 \%$; third-level: $54 \% / 88 \%$ ) and information (second-level: $31 \% / 40 \%$; third-level: $31 \% / 68 \%$ ).

The variable 'supervisor's way of functioning' correlates strongly with the variable 'social climate' in both years and in both the staff's and managers' data (Table 5). In addition to the individual-level analysis, aggregate-level data were formed using municipalities as units of observation, with the mean value of the answers in the specified variable used for the specified municipality. With these data, it was possible to measure the changes in the supervisor's way of functioning from 2009 to 2011. This variable, indicating change, correlated clearly positively (sig. $\mathrm{p}<0.05)$ to the value of 'social climate' in 2011. There are also minor positive correlations with 'influence at work' and 'intrinsic rewards of work' (Table 6). The importance of the relationship found between 'supervisor's way of functioning' and 'social climate' is further strengthened by the results of the partial correlations. As regards, for example, 'intrinsic rewards of work,' the correlations can be interpreted to be to a great extent a result of the joint effects of the 'supervisor's way of functioning' and 'social climate' rather than as a separate effect. In partial 
Table VI Relations of the supervisor's way of functioning to influence at work, social climate, and intrinsic rewards of work (aggregate-level correlations)

\begin{tabular}{lccc}
\hline & Influence & Social climate & Intrinsic rewards \\
\hline $\begin{array}{l}\text { Change in manager's way of functioning } \\
\text { 2009-201 I }\end{array}$ & 0.14 & $0.35^{\times}$ & 0.18 \\
\hline
\end{tabular}

Note: Municipalities as observation units; statistical significance: ${ }^{\times} p<0.05$.

Table VII Correlations between variables 'intrinsic rewards,' 'social climate,' and 'supervisory work' in 201। (total data)

\begin{tabular}{lcc}
\hline & \multicolumn{1}{c}{ Intrinsic rewards } \\
\hline & Correlation & Partial correlation \\
\hline Supervisory work & $0.38^{\times \times x}$ & $0.15^{\times \times x}$ (climate controlled) \\
\hline Social climate & $0.41^{\times \times x}$ & $0.23^{\times \times x}$ (supervisory controlled $)$ \\
\hline
\end{tabular}

Note: Statistical significance: ${ }^{x \times} p<0.001$.

correlations when one or another of these variables are controlled, the correlations with 'intrinsic rewards' reduce clearly (Table 7).

\section{Discussion}

This article has sought to address the issue of line manager agency in the midst of broadscale municipal reform. The focus of the article has been on the conditions of agency. Agentic behavior-which in itself is a very interesting issue-is beyond the scope of this article.

The stages of reform in the public sector take place in successive waves; the time between each stage varies from case to case. In evaluations of the reforms, the stages relate to immediate, intermediate, and final outcomes (e.g., Mayne 2008). Municipal mergers, local government comanagement areas, and other collaborative efforts can be considered as the first stage of reform, which offers developmental potential, that is, opportunities for improving municipal operations (Meklin \& Pekola-Sjöblom 2013, p. 12). The next stage includes renewals in the systems of management and the resultant organizational restructuring. The third stage involves the reform proceeding to the level of service provision and community development. In the reform described in this article, the municipalities had renewed their operations in several ways as a result, for example, of changes in the management systems and organizational structures.

The article has approached the issue of change agency from the perspectives of managers as both targets and agents of change. This double approach is justified since the conditions of being a target of change may essentially influence the conditions of being an agent of change.

Since the municipalities were at different stages of the reform process, the first task of the analysis was to check possible influences of this fact. Since the differences were minor, the analysis proceeded without the differentiation of the municipalities according 
to the specific model of the reform. The study has covered preconditions of agency related both to one's immediate work and workplace and to the broader issues of the reform at the municipality level. These two fields of agency showed different patterns of results, indicating different kinds of resources and constraints in each field.

In the variables 'influence at work' and 'intrinsic rewards of work,' the predominant pattern of results was increasing values according to the hierarchical level of the positions of the respondents. However, in 'opportunities to develop one's workplace' and 'information concerning changes in one's work,' there was a clear decline among the manager groups from 2009 to 2011. This result requires further deliberation. In 'opportunities to participate in reform planning' and 'information concerning the reform,' there was a clear increase in the pattern of the results according to the hierarchical position. The low values in the staff group and also in the first-level manager group were noteworthy. The supervisor's ways of functioning correlated strongly with the social climate, and the connection was visible also in the longitudinal setting.

Reflecting on the results, the research literature provides alternative perspectives. Strategic agency literature concerning middle managers asks in what ways middle managers are or might be influential in strategy processes. Wooldridge et al. (2008, p. 1195) differentiate three broad topics in those studies: strategic roles and their antecedents, middle managers' involvement in strategy and organizational cognition, and the relationship between middle management strategic behavior and organizational outcomes. These studies apply a wide variety of theoretical constructs and methodological approaches. The issue of opportunities to participate in the reform-planning process seems to imply that participation in the planning was not only the task of top managers. Our study does not specify the channels through which participation in the planning takes place. Literature on middle management defines middle managers as individuals working in positions at the intersection of information flows (Nonaka et al. 2000, pp. 22-23) who transmit ideas upward and implement decisions downward (Wooldridge et al. 2008, p. 1203) and function as change intermediaries who interpret change events (Balogun 2003, p. 79). Admittedly, the hierarchical structure of the respondents' positions is visible in the answers. The fact that opportunities for participation existed at all levels-at least for some of the respondents-also leads to alternative perspectives for the interpretation of the results.

While the mainstream of studies on strategy processes have emphasized the role of top managers, a number of researchers have concentrated on the distributed nature of agency instead (Buchanan et al. 2007; Caldwell 2003; Charles \& Dawson 2011). According to these researchers, it is not only the top levels who make contributions to change processes; other employees do so too. The distributed agency perspective redefines the concept of strategy. For example, Jarzabkowski et al. (2007, pp. 7-8) present strategy as a situated, socially accomplished activity, and the strategic nature of the activities is deduced from the extent that the activities are consequential to the strategic outcomes, directions, survival, and competitive advantage of the firms. The focus of such studies is on micro-level activities (Mantere 2008) rather than on top-down decisionmaking processes. From the point of view of agency, a key issue is the extent to which actors in different functions and on different levels of hierarchy are empowered in activities that contribute to change processes (Caldwell 2003).

In the variable 'influence at work' the main dividing line was, overall, between the staff and the managers. Worthy of attention are the areas where opportunities to 
influence existed or did not exist. Some of the items indicate better than others the conditions that may lead to strategic influence. An example of the former is 'opportunity to influence the setting of objectives in the workplace,' and an example of the latter is 'opportunity to influence one's working methods.' However, one should be aware that workplace-level improvements and renewals in conducting the work might be the starting point that leads to improvements in service processes on a broader scale. Thus, we consider there to be numerous aspects of autonomy that might be influential in changes, starting from decisions in one's own work to influence on decision-making processes among the upper levels.

Giddens (1984) binds together two conditions which may lead to agency, that is, knowledgeability and the autonomy to act differently. A positive result from the point of view of agency was high values in the variable 'intrinsic rewards of work,' which may be considered an operationalization of enabling conditions for using cognitive resources at work. The values were nearly as high among the staff as they were in the manager groups. A tentative conclusion of this result is the existence of the potential for meeting new cognitive and learning challenges resulting from the change processes.

Studies of organizational change have underlined the importance of culture and social climate (Kanter 1983, pp. 149-152) as well as communication and the free flow of information in general (Allen et al. 2007; Frahm \& Brown 2007; Kanter 1982). Organizational changes tend to produce uncertainties among employees and the daily actions and climate of interaction are of importance in handling and alleviating feelings caused by uncertainties (Allen et al. 2007; Giauque 2015; Karp \& Helgo 2008). The consequences of interaction may reach beyond the individual level and have an effect on the change process itself.

The studies of so-called sense-making agency understand strategy as the emerging result of the interaction of a multitude of actors from different levels of the organization rather than as a deliberate result of a rational policy-planning process (Caldwell 2009). From the perspective of sense-making agency, the nature of the social environment can be considered highly important as a prerequisite of agency. The finding of a strong connection between supervisor activity and social climate is notable from this perspective. It might be interpreted both as a field of influence by the supervisors and as an immediate context of agency.

A puzzling result is the clear reduction of the numbers of those who consider themselves as having good opportunities to participate in the development of the workplace. This reduction concerned all manager groups. Another reduction in the manager groups was in the number of those who get information of changes related to their work already at the planning stage. A possible explanation might relate to the kind of change processes in large-scale reforms. In municipalities, the channels and forms of influence are quite different at the different stages of the reform process. In 2011, major decisions were made concerning whether the municipality continued alone, merged with other municipalities, or joined some cooperation areas (for the time being-a new round of negotiations and speculations started afterward as the result of new government plans that created new rules for organizing social and health care services). The demands of work in 2011 concerned the adaptation to the organization's chosen structures.

The differences in the prerequisites of agency at the different stages of the reform process have some analogy to those depicted in the contrasting models of linear and emerging or self-organizing organizational changes (Higgs \& Rowland 2005; Lichtenstein 1997). 
In linear change in key roles are top-down decision-making processes while in emerging change both horizontal and vertical interaction relationships influence the processes. We can only speculate on the reasons for the reduction in opportunities to influence development in the workplace shown by the manager groups. It is possible that managers have had better opportunities than the staff to influence the broad lines of development but not the details in the everyday life of the organization. It is also possible that new demands and expectations have been placed on the managers' work that are not so easy to act upon in the day-to-day context of the work. Taking into account the high values the managers gave for the intrinsic rewards of work, motivational tension should not be excluded either. It is possible that cognitive and learning potential do not actualize in the accomplishment of the development activities to a satisfactory extent.

\section{Limitations and challenges}

Extant literature provides numerous strands of studies that relate in one way or another to the work of line managers. Some of them are quite established in terms of theory, topics, and methods, whereas others are less so. With the focus on agency, this study belongs to the latter group. Agency in the context of organizational change is a broad issue. There are different theoretical and methodological approaches that provide diverging perspectives on the issue. This study suggests that in successive stages of large-scale reforms, different theoretical perspectives might be of value. In large-scale reforms, there are problems with outlining the research setting that further studies should take into consideration. Large-scale reforms are not like bounded interventions that start and end at definite times. Rather, they involve several successive and simultaneous processes and actors inside and outside the organization.

\section{Conclusion}

Reforms in local government are ongoing in many countries. This is due to the pressures of providing services in cost-effective ways while at the same time dealing with increases in service demand caused by demographic changes. This study relates to the nation-wide reform in Finland. Evaluation results on reforms often tend to be ambiguous. Reforms take place under political pressures, and typically there is a rush to achieve the objectives defined by the reforms. However, large-scale reforms proceed in stages and before the effects can be recognized, the process has to proceed to the grassroots level where services are provided.

This study focused on the preconditions of the agency of line managers. Unlike the mainstream of middle manager studies, this study included managers from different hierarchical levels and staff members from the same units. This research design made it possible to make comparisons between different groups of actors.

In many of the variables, the results followed the respondents' hierarchical positions, indicating better conditions for agency according to a higher position in the hierarchy. However, opportunities for influence were not altogether missing from the other groups. Such a scenario might indicate the preconditions of distributed—even though limited-agency. 
Worthy of attention was the strong connection between supervisor activity and the social climate of the units. This relation was also confirmed in the longitudinal setting. Especially in terms of distributed agency, the organization's social climate can be considered to be of utmost importance.

Another noteworthy result was the high values given to the variable 'intrinsic rewards of work.' In the reforms, structural changes may provide the preconditions to achieve objectives, for example, producing cost-effective, high-quality services. However, the reform wastes its opportunities if it does not utilize the innovative potential of the staff and managers to do the work differently. This result was interpreted as indicating that enabling conditions for meeting new cognitive and learning challenges were in place.

The third noteworthy result was the reduction in managers' opportunities to influence development in their workplaces. In large-scale reforms, it is necessary to be aware of the progress of the reform at separate stages. It is possible that at different stages, different theoretical models of change are required when interpreting the results. The stage at which structural reform decisions are made, the stage at which renewals in the systems of management and organizational renewals are made, and the stage at which renewals proceed to the provision of the grassroots level of service require partly different actors and forms of agency. There are different factors that alone or jointly might be behind the observed reduction in the development opportunities by managers in the micro-level context. These factors could be rules and regulations, organizational arrangements, formal and informal expectations, and the personal ambitions of managers.

\section{References}

Act on Municipal Structure (478/2013) Finland.

Act on Restructuring Local Government and Services (169/2007) Finland.

Alfes, K., Truss, C., Soane, E.C., Rees, C. \& Gatenby, M. (2013) 'The relationship between line manager behavior, perceived HRM practices, and individual performance: Examining the mediating role of engagement', Human Resource Management, 52, 839-859.

AFLRA (2015) Website of Association of Finnish Local and Regional Authorities. www. kunnat.net/fi/palvelualueet/kuntauudistus/Sivut/default.aspx. Accessed August 31, 2015.

Allen, J., Jimmieson, N.L., Bordia, P. \& Irmer, B.E. (2007) 'Uncertainty during organizational change: Managing perceptions through communication', Journal of Change Management, 7, 187-210.

Balogun, J. (2003) 'From blaming the middle manager to harnessing its potential: Creating change intermediaries', British Journal of Management, 14, 69-83.

Blöchliger, H. \& C. Vammalle (2012) Reforming Fiscal Federalism and Local Government: Beyond the Zero-Sum Game, OECD Fiscal Federalism Studies, OECD Publishing, Paris. http://dx.doi.org/10.1787/9789264119970-en. Accessed August 31, 2015.

Borge, L.E. \& Rattso, J. (2012) 'Fiscal federalism. International experiences and the Nordic response', In A. Moisio (Ed.) Rethinking Local Government: Essays on Municipal Reform (pp. 15-42). Helsinki: Government Institute for Economic Research.

Bos-Nehles, A.C., van Riemsdijk, M.J. \& Looise, J.K. (2013) 'Employee perceptions of line manager performance: Applying the AMO theory to explain the effectiveness of line managers' HRM implementation', Human Resource Management, 52, 861-877.

Brewster, C., Gollan, P.J. \& Wright, P.M. (2013) 'Guest editors’ note: Human resource management and the line', Human Resource Management, 52, 829-838. 
Bryant, M. \& Stensaker, I. (2011) 'The competing roles of middle management: Negotiated order in the context of change', Journal of Change Management, 11, 353-373.

Buchanan, D.A., Addicott, R., Fizgerald, L., Ferlie, E. \& Baeza, J.I. (2007) 'Nobody in charge: Distributed change agency in healthcare', Human Relations, 60, 1065-1090.

Caldwell, R. (2003) 'Change leaders and change managers: Different or complementary?', Leadership \& Organization Development Journal, 24, 285-293.

Caldwell, R. (2005) 'Things fall apart? Discourses on agency and change in organizations', Human Relations, 58, 83-114.

Caldwell, R. (2009) 'Change from the middle? Exploring middle manager strategic and sensemaking agency', In R. Todnem \& C. Macleod (Eds.) Managing Change in Public Services (pp. 74-96). London: Routledge.

Charles, K. \& Dawson, P. (2011) 'Dispersed change agency and the improvisation of strategies during processes of change', Journal of Change Management, 11, 329-351.

CS (2011) Programme of Prime Minister Jyrki Katainen's Government. Council of State.

http://valtioneuvosto.fi/documents/10184/367809/Programme+of+Prime+Minister+Katain en $\%$ E2\% 80\%99s+Government/64238eca-58cd-43bb-81dc-963a364a422e. Accessed August 31, 2015.

Dafflon, B. (2012) Voluntary amalgamation of local governments: The Swiss debate in the European context (Working Paper No 4). Atlanta: Georgia State University, International Center for Public Policy.

Davis, L.E. \& Cherns, A.B. (Eds.) (1975) The Quality of Working Life. Problems, Prospects and the State of the Art. London: Collier MacMillan Publishers.

Denters, B. \& Rose, L.E. (2005) Comparing Local Governance. Trends and Developments. Basingstoke: Palgrave MacMillan.

Dollery, B.E., Carcea, J. \& Lesage, E.E. (2008) Local Government Reform. A Comparative Analysis of Advanced Anglo-American Countries. Northampton: Edward Elgar Publishing.

Dutton, J.E., Ashford, S.J., O’Neill, R.N. \& Lawrence, K.A. (2001) 'Moves that matter: Issue selling and organizational change', Academy of Management Journal, 44, 716-736.

Emery, F.E. \& Thorsrud, E. (1969) Form and Content in Industrial Democracy-Some Experiences from Norway and Other European Countries. London: Tavistock.

Eteläpelto, A., Vähäsantanen, K., Hökkä, P. \& Paloniemi, S. (2013) 'What is agency? Conceptualizing professional agency at work', Educational Research Review, 10, 45-65.

Frahm, J. \& Brown, K. (2007) 'First steps: Linking change communication to change receptivity, Journal of Organizational Change Management, 20, 370-387.

Gallie, D. (2013) 'Direct participation and the quality of work', Human Relations, 66, 453-473.

Gerstner, C. \& Day, D.V. (1997) 'Meta-analytic review of leader-member exchange theory: Correlates and construct issues', Journal of Applied Psychology, 82, 827-844.

Giauque, D. (2015) 'Attitudes toward organizational change among public middle managers', Public Personnel Management, 44(1), 70-98.

Giddens, A. (1984) The Constitution of Society: Outline of the Theory of Structuration. Berkeley, CA: University of California Press.

Haveri, A. (2008) 'Evaluation of change in local governance', Evaluation, 14, 141-155.

Higgs, M. \& Rowland, D. (2005) 'All changes great and small: Exploring approaches to change and its leadership', Journal of Change Management, 5, 121-151.

Huy, Q.N. (2002) 'Emotional balancing of organizational continuity and radical change: The contribution of middle managers', Administrative Science Quarterly, 47, 31-69.

Jansson, N. (2013) 'Organizational change as practice: A critical analysis', Journal of Organizational Change Management, 26, 1003-1019.

Jarzabkowski, P., Balogun, J. \& Seidl, D. (2007) 'Strategizing: The challenges of a practice perspective', Human Relations, 60, 5-27. 
Jokinen, E. \& Heiskanen, T. (2013) Henkilöstö uudistusten pyörteissä II. (Local government personnel in the face of reforms.) Paras-ARTTU research program studies no 27. Helsinki: Finnish Association of Local and Regional Authorities. (Acta 247).

Kanter, R.M. (1982) 'The middle manager as innovator', Harvard Business Review, 60(4), 95-105.

Kanter, R.M. (1983) The Change Masters. New York: Simon \& Schuster.

Karp, T. \& Helgo, T.I.T. (2008) 'From change management to change leadership: Embracing chaotic change in public service organizations', Journal of Change Management, 8, 85-96.

Larsen, H.H. \& Brewster, C. (2003) 'Line management responsibility for HRM: What is happening in Europe?', Employee Relations, 25, 228-244.

Lichtenstein, B.M. (1997) 'Grace, magic and miracles. A "chaotic logic" of organizational transformation', Journal of Organizational Change Management, 10, 393-411.

Lines, R. (2004) 'Influence of participation in strategic change: Resistance, organizational commitment and change goal achievement', Journal of Change Management, 4, 193-215.

Macleod, C. \& By, R.T. (2009) 'An overview of managing organizational change in public services', In R.T. By \& C. Macleod (Eds.) Managing Organizational Change in Public Services. International Issues, Challenges and Cases (pp. 3-15). London \& New York: Routledge.

Mantere, S. (2008) 'Role expectations and middle manager strategic agency', Journal of Management Studies, 45, 294-316.

Mayne, J. (2008) Contribution analysis: An approach to exploring cause and effect. ILAC Brief, 16.

McConville, T. (2006) 'Devolved HRM responsibilities, middle-managers and role dissonance', Personnel Review, 35, 637-653.

Meklin, P. \& Pekola-Sjöblom, M. (2013) Municipalities Measured. Evaluation of the initial situation and development potential of local authorities participating in the PARAS reform. Abstract. Summary report on Evaluation Research Programme ARTTU 2010

Evaluation Research Programme ARTTU Studies No. 4. An Acta Plus

Publication. Association of Finnish Local and Regional Authorities. http://www.localfinland. fi/en/association/research/arttu/reports/Documents/ARTTU\%20kokoomaraportti\%20 eng.pdf. Accessed August 31, 2015.

Meklin, P. \& Pekola-Sjöblom, M. (2013) The Reform to Restructure Municipalities and Services in Finland: A Research Perspective (ARTTU studies No 23). Helsinki: Association of Finnish Local and Regional Authorities.

Moisio, A. (2012) 'Introduction', In A. Moisio (Ed.) Rethinking Local Government: Essays on Municipal Reform (pp. 1-14). Helsinki: Government Institute for Economic Research.

Naschold, F. (1996) New Frontiers in Public Sector Management. Berlin: Walter de Gruyter.

Newell, H. \& Dopson, S. (1996) 'Muddle in the middle: Organizational restructuring and middle management careers', Personnel Review, 25(4), 4-20.

Nonaka, I. (1994) 'A dynamic theory of organizational knowledge creation', Organization Science, 5, 14-37.

Nonaka, I., Toyama, R. \& Konno, N. (2000) 'SECI, Ba and leadership: A unified model of dynamic knowledge creation', Long Range Planning, 33, 5-34.

Paglis, L.L. \& Green, S.G. (2002) 'Both sides now: Supervisor and subordinate perspectives on relationship quality', Journal of Applied Social Psychology, 32, 250-276.

Pollit, C. \& Bouckaert, G. (2000) Public Management Reform: A Comparative Analysis. Oxford: Oxford University Press.

Poole, M., Mansfield, R. \& Gould-Williams, J. (2006) 'Public and private sector managers over 20 years: A test of the "convergence thesis"', Public Administration, 84, 1051-1076.

Poutsma, E. \& Veersma, U. (2010) 'Direct and indirect participation: Reconcilable voices? Report from Stream I', In F. Garibaldo \& V. Telljohann (Eds.) The Ambivalent Character of 
Participation. New Tendencies in Worker Participation in Europe (pp. 25-32). Frankfurt am Main: Peter Lang.

Rose, L.E. \& Ståhlberg, K. (2005) 'The Nordic countries: Still the promised land?', In L.E. Rose \& B. Denters (Eds.) Comparing Local Governance. Trends and Developments (pp. 83-99). Basingstoke: Palgrave Macmillan.

Russ, T.L. (2008) 'Communicating change: A review and critical analysis of programmatic and participatory implementation approaches', Journal of Change Management, 8, 199-211.

Schyns, B. \& Day, D. (2010) 'Critique and review of leader-member exchange theory: Issues of agreement, consensus, and excellence', European Journal of Work and Organizational Psychology, 19, 1-29.

Slack, E. \& Bird, R.M. (2012) 'Merging municipalities: Is bigger better?’, In A. Moisio (Ed.) Rethinking Local Government: Essays on Municipal Reform (pp. 83-130). Helsinki: Government Institute for Economic Research.

Tierney, P. (1999) 'Work relations as precursor to a psychological climate for change', Journal of Organizational Change, 12, 120-133.

Wollman, H. (2012) 'Local government reforms in (seven) European countries: Between convergent and divergent, conflicting and complementary developments', Local Government Studies, 38, 41-70.

Wooldridge, B., Schmid, T. \& Floyd, S.W. (2008) 'The middle management perspective on strategy process: Contributions, synthesis, and future research', Journal of Management, 34, 1190-1221.

Appendix I: Quality of Working Life (QWL, alpha = 0.79) Sum Variables

Intrinsic rewards of work (alpha $=0.85)$

K2107 Work develops the worker.

K2105 Work is interesting.

K2106 Work requires me to learn new things.

K2109 Work is varied.

K2112 One can use one's know-how in work.

K2111 One can achieve one's goals in work.

K2110 Work requires responsibility.

Work influence $($ alpha $=0.83)$

K1003 On pace of the work.

K1002 On order of your tasks.

K1001 On what is included into your tasks.

K1004 On your working methods.

K1005 On how work is being divided among people.

K1006 On whom you are working with.

Social climate at workplace (alpha $=0.86)$

K1106 Atmosphere at our workplace is encouraging.

K1107 Tasks at our workplace are well organized.

K1109 Know-how is being appreciated at our workplace.

K1104 Information is being transmitted openly at our workplace.

K1108 There is positive attitude toward changes at our workplace.

K1102 People can really be trusted at our workplace. 
Open ways to solve work conflicts (alpha $=0.89$ )

K2307 Conflicts are being discussed openly at the workplace and we try to find a solution which benefits all.

K2306 When conflict appears, we try to find a compromise solution which satisfies all.

K2308 When conflict appears, we search for a reasonable solution which is based on expertise.

K2304 Open coming up of conflicts is being encouraged.

Supervisory work (alpha $=0.94)$

K2411 My supervisor builds up trust.

K2408 My supervisor supports and encourages me.

K2412 My supervisor acts fair and equal.

K2402 My supervisor is inspiring.

K2410 My supervisor appreciates my know-how.

K2407 My supervisor shares responsibilities in a reasonable way among workers.

K2403 My supervisor tells openly about all work-related matters.

K2404 My supervisor trusts her workers.

K2409 My supervisor knows my tasks well.

K2406 My supervisor encourages workers to educate themselves and develop in their work. 